\title{
Pengaruh Pemberian Jus Lidah Buaya (Aloe vera) terhadap Berat Potong, Berat Karkas, Non Karkas dan Lemak Abdominal Ayam Broiler
}

Wilhelmus Subani

Fakultas Pertanian, Universitas Timor, Kefamenanu, TTU - NTT, Indonesia, email: mussubani@gmail.com

\section{Article Info}

\section{Article history:}

Received 12 April 2019

Received in revised form 15 Desember 2019 Accepted 10 Januari 2020

DOI:

https://doi.org/10.32938/ja.v5i1.885

Keywords:

Broiler

Jus lidah buaya

Karkas

Lemak abdominal

\section{Abstrak}

Penelitian ini bertujuan untuk mengetahui pengaruh pemberian jus lidah buaya terhadap berat potong, karkas, dan lemak abdominal ayam broiler. Penelitian ini dilaksanakan di kandang unggas milik Program Studi Peternakan Fakultas Pertanian. Penelitian ini menggunakan metode eksperimen dengan Rancangan Acak Lengkap (RAL) yang terdiri dari 4 perlakuan dan 4 ulangan sehingga terdapat 16 unit percobaan dan setiap unit percobaan terdiri dari 5 ekor ayam broiler. Perlakuan yang diberikan adalah P0: 100\% air minum, P1: $95 \%$ air minum $+5 \%$ jus lidah buaya, P2: $90 \%$ air minum $+10 \%$ jus lidah buaya, $\mathrm{P} 3: 85 \%$ air minum $+15 \%$ jus lidah buaya. Variabel yang diamati adalah berat potong berat karkas, berat non karkas dan berat abdominal ayam broiler. Analisis sidik ragam menunjukkan bahwa pemberian jus lidah buaya sebagai feed additive berpengaruh nyata $(\mathrm{P}<0,05)$ terhadap persentase berat karkas, berat potong, berat dan persentase lemak abdominal pada ayam broiler tetapi berpengaruh tidak nyata terhadap berat karkas pada ayam broiler. Disimpulkan bahwa pemberian $10 \%$ jus lidah buaya dalam air minum sebagai feed additive memberikan hasil terbaik terhadap kinerja ayam broiler.

\section{Pendahuluan}

Ayam broiler atau ayam pedaging adalah jenis ayam yang telah lama mengalami upaya pemuliaan, bentuk, ukuran dan warna yang seragam. Ayam broiler adalah jenis unggas yang telah mengalami seleksi gen bertahun-tahun, sehingga hanya dalam waktu produksi 35-40 hari sudah layak dikonsumsi. Untuk dapat di panen dalam waktu singkat maka jumlah pakan memegang peran penting.

Pakan sebagai tolak ukur dalam memperoleh kuantitas dan kualitas produksi ternak yang diinginkan. Untuk meningkatkan produktivitas yang efisien secara teknis dan ekonomis, maka perlu dicari berbagai alternatif dalam penyediaan pakan yang dapat memenuhi kebutuhan biologis ternak dan harganya relatif murah. Tujuan akhir pemeliharaan ayam broiler pada umumnya adalah untuk memproduksi daging yang banyak serta dapat memperbaiki efisiensi pakan. Biasanya dalam pemeliharaan ayam pedaging, salah satu usaha yang dilakukan untuk memperbaiki efisiensi pakan adalah dengan menambahkan feed additive.

Feed additive yang sudah lama digunakan pada peternak ayam broiler adalah antibiotik. Mekanisme kerja dari antibiotik pada perinsipnya adalah untuk mengurangi populasi mikroorganisme didalam saluran pencernaan sehingga meningkatkan ketersediaan zat gizi ransum dan penyerapannya dan akhirnya memacu pertumbuhan ternak. Imbuhan pakan antibiotik dapat meningkatkan pertumbuhan ayam, namun penggunaan antibiotik secara terus menerus dapa menyebabkan mikroba yang bersifat positif mati dan dapat menyebabkan residu pada hati dan daging.

Untuk mencegah timbulnya residu pada daging dan hati maka penggunaan antibiotik dapat digantikan degan menggunakan tanaman lidah buaya dalam bentuk tepung lidah buaya (Aloe vera). Aloe vera mengandung anthrakinon yang dapat berfungsi untuk menurunkan populasi organisme pathogen dalam saluran pencernaan selain itu lidah buaya mengandung saponin yang dapat meningkatkan penyerapan zat gizi (Sinurat et al., 2002). Tujuan dari penelitian ini adalah untuk mengetahui pengaruh pemberiangel lidah buaya terhadap berat potong, berat karkas dan lemak abdominal ayam broiler.

\section{Metode}

\subsection{Waktu dan Lokasi Penelitian}

Penelitian ini dilaksanakan di kandang unggas milik Program Studi Peternakan, Fakultas Pertanian, Universitas Timor. Penelitian ini berlangsung selama 6 minggu, terhitung dari bulan November 2018 - Januari 2019.

\subsection{Materi Penelitian}

\subsubsection{Ternak}

Ternak yang dipakai dalam penelitian ini adalah ayam broiler umur sehari atau day old chick (DOC) PT Wonokoyo berjumlah 80 ekor.

\subsubsection{Bahan}

Bahan yang digunakan dalam penelitian ini terdiri ransum komersial yaitu pakan komersial BR1 diberikan pada umur 0-4 minggu untuk ternak pada fase starter dan BR2 diberikan pada umur 4-6 minggu untuk ternak pada fase finisher. 2.2.3 Alat

Alat yang digunakan yaitu pagar bambu untuk pembatas antar kandang, tirai plastik sebagai penutup kandang, tempat pakan, tempat minum, termohigrometer untuk mengukur suhu dan kelembaban, sekam, sekop dan disinfektan untuk peralatan sanitasi kandang, pita ukur untuk mengukur panjang, timbangan untuk pakan, bobot badan ayam serta mengukur bobot karkas, bobot potong dan berat lemak abdominal dan alat tulis.

\subsection{Rancangan Percobaan}

Penelitian ini menggunakan metode eksperimen degan rancangan acak lengkap (RAL) yang terdiri dari 4 perlakuan dan 4 ulangan sehingga terdapat 16 unit percobaan. Masing-masing unit percobaan terdapat 5 ekor broiler. Perlakuan yang diberikan pada ayam broiler adalah:

$\mathrm{P}_{0}=100 \%$ air minum tanpa jus lidah buaya
$\mathrm{P}_{1}=95 \%$ air minum $+5 \%$ jus lidah buaya

$\mathrm{P}_{2}=90 \%$ air minum $+10 \%$ jus lidah buaya

$\mathrm{P}_{3}=85 \%$ air minum $+15 \%$ jus lidah buaya

\subsection{Prosedur Penelitian}

2.4.1 Persiapan jus lidah buaya

Lidah buaya diperoleh dipotong dan dibuang kulitnya (bagian daun lidah buaya) sehingga tertinggal bagian isinya (gel). Kemudian isi lidah buaya dibersihkan dari kotoran dengan air mengalir, kemudian di blender sampai halus dan dicampur dalam air minum.Volume air yang digunakan saat blender adalah $100 \mathrm{ml}$ dan $1000 \mathrm{gr}$ daging lidah buaya.

Pembutan kandang: petak kandang dibuat sebanyak 16 petak dan setiap petak berukuran $1 \times 0,5 \mathrm{~m}$. Kandang dibuat dengan sistim lorong dan terdiri dar dua bagian yaitu pada sisi kiri dan sisi kanan. Kandang terbuat dari bilah bambu.

Pemberian ransum: ransum adalah pakan lokal yang diberi pada ayam yang berumur 15 sampai 45 hari. Pemeliharaan ini berlangsung dari awa penelitian sampai akhir pemotongan. Ransum diberikan sekali dalam sehari dalam bentuk grit dan disesuaikan dengan tingkat konsumsi pakan.

Pemeliharaan: pemeliharan dalam indukan buatan sampai umur 2 minggu. Ayam broiler divaksin pada umur 3 hari dan 21 hari kandang perlu dilakukan sanitasi kandang, persiapan pakan dan minuman serta melakukan vaksinasi, dan ransum yang diberikan berbentuk grit.

Pengambilan data. Data yang diambil dalam penelitian ini adalah berat potong, berat karkas dan lemak abdominal yang diambil pada akhir penelitian.

\subsection{Variabel Penelitian}

Variabel yang diamati dalam penelitian ini adalah:

1. Berat hidup (g/ekor): Berat hidup diperoleh dari hasil penimbangan ternak dimana sebelum disembelih ternak dipuasakan selama 12 jam.

2. Berat Karkas (g/ekor) : Berat karkas diperoleh dari hasil penimbangan bagian tubuh ternak setelah disembelih dan dikeluarkan bulu, darah, kepala,kaki, jeroan.

3. Berat Non Karkas (g/ekor): Berat Non Karkas yang diperoleh dari hasil peningbangan ternak setelah disembelih dan sebelum dikeluarkan bulu darah, kepala, kaki, jeroan.

4. Berat Lemak Abdominal (g/ekor): Berat Lemak Abdominal yang diperoleh dari hasil tubuh ternak yang setelah disembelih dan dikeluarkan semua organ dalam lalu dipisahkan lemak yang menempel pada bagian rempela.

\subsection{Analisis Data}

Data dianalisis dengan menggunakan analisis sidik ragam (Anova) dan dilanjutkan dengan Uji Jarak berganda Duncan menurut Steel and Torrie (1995) untuk melihat perbedaan.

\section{Hasil dan Pembahasan}

\subsection{Pengaruh Perlakuan Terhadap Berat Potong ayam broiler}

Bobot potong adalah bobot yang didapat dengan cara menimbang bobot akhir ayam setelah dipuasakan selama \pm 4 jam. Rata-rata bobot potong ayam broiler pada penelitian ini adalah $1053,19 \mathrm{~g}$ /ekor. Rataan bobot potong tertinggi pada perlakuan $\mathrm{P}_{2}$ dan terendah pada perlakuan $\mathrm{P}_{0}$. Bobot potong yang diperoleh pada penelitian ini $\left(\mathrm{P}_{1}\right.$ dan $\left.\mathrm{P}_{2}\right)$ lebih tinggi jika dibandingkan dengan standar ratarata bobot potong yang dikeluarkan oleh Charoen Pokphan (2004) bahwa rataan bobot potong normal ayam broiler umur 6 minggu adalah 1053,19 g/ekor. Ratarata berat potong ayam broiler adapt dilihat pada Tabel 1 .

Analisis statistik menunjukkan bahwa perlakuan berpengaruh nyata $(\mathrm{P}<0,05)$ terhadap berat potong ayam broiler. Hal ini sebagai akibat dari pemberian jus lidah buaya karena pada jus lidah buaya mengandung zat zat yang dapat memacu metabolisme, seperti kelompok antrakuinon, berbaga mineral, vitamin, enzim dan asam amino. Namun, apabila berlebihan diberikan 
pada ayam broiler maka pertambahan bobot badan ayam akan menurun. Palatabilitas pakan yang menurun menyebabkan konsumsi pakan juga menurun dan berimplikasi terhadap pertambahan bobot badan.

Tabel 1. Rata-rata berat bobot potong ayam broiler (g/ekor).

\begin{tabular}{|c|c|c|c|c|c|}
\hline \multirow{2}{*}{ Ulangan- } & \multicolumn{4}{|c|}{ Perlakuan } & \multirow{2}{*}{ Jumlah } \\
\hline & $\mathrm{P}_{0}$ & $\mathrm{P}_{1}$ & $\mathrm{P}_{2}$ & $\mathrm{P}_{3}$ & \\
\hline 1 & 919 & 961 & 1137 & 1147 & \\
\hline 2 & 768 & 973 & 1181 & 1177 & \\
\hline 3 & 902 & 809 & 1347 & 1026 & \\
\hline 4 & 1048 & 1230 & 1044 & 1182 & \\
\hline Jumlah & 3637 & 3973 & 4709 & 4532 & 16.851 \\
\hline Rataan & $909,25^{\mathrm{b}}$ & $993,25^{\mathrm{ab}}$ & $1177,25^{\mathrm{a}}$ & $1133^{a}$ & 1053,19 \\
\hline
\end{tabular}

Sinurat et al. (2002) menambahkan bahwa perbedaan ini juga dapat disebabkan oleh perbedaan jumlah kandungan zat bioaktif dalam lidah buaya yang digunakan karena variasi kesegaran tanamannya, di samping faktor lain seperti metode penyiapan yang berubah bubuk, ekstrak, atau bagian herbal. Dilanjutkan pula bahwa penggunaan lidah buaya yang di campurkan dalam air ayam broiler dapat meningkatkan performa ayam broiler sebagai akibat dari meningkatnya daya cerna zat gizi.

\subsection{Pengaruh Perlakuan Terhadap Persentase Berat Karkas Ayam Broiler}

Persentase karkas seekor ayam erat hubungannya dengan bobot hidup ayam waktu panen. Selain itu, bagian dari ransum yang sangat berpengaruh untuk pembentukan karkas adalah kandungan protein ransum (Setiadi et al., 2013). Rataan berat karkas ayam broiler yang diberikan jus lidah buaya dalam air minum terteral pada Tabel 2.

Tabel 2. Rata-rata berat karkas ayam broiler (g/ekor)

\begin{tabular}{|c|c|c|c|c|c|}
\hline \multirow{2}{*}{ Ulangan } & \multicolumn{4}{|c|}{ Perlakuan } & \multirow{2}{*}{ Jumlah } \\
\hline & $\mathrm{P}_{0}$ & $\mathrm{P}_{1}$ & $\mathrm{P}_{2}$ & $\mathrm{P}_{3}$ & \\
\hline 1 & 570 & 607 & 768 & 741 & \\
\hline 2 & 469 & 635 & 728 & 785 & \\
\hline 3 & 576 & 489 & 885 & 642 & \\
\hline 4 & 686 & 729 & 766 & 586 & \\
\hline Jumlah & 2301 & 2460 & 3147 & 2754 & 10.662 \\
\hline Rataan & $575,25^{\mathrm{b}}$ & $615,00^{\mathrm{b}}$ & $786,75^{\mathrm{a}}$ & $688,50^{\mathrm{ab}}$ & 666,38 \\
\hline
\end{tabular}

Pada Tabel 2 terlihat bahwa rata-rata berat karkas ayam broiler selama penelitian secara keseluruhan adalah 666,38 g/ekor sedangkan untuk masingmasing perlakuan yang tertinggi terdapat pada $\mathrm{P}_{2}$ yaitu 786,75 g/ekor dan yang terendah pada $\mathrm{P}_{0}$ yaitu 575,25 g/ekor. Analisis statistik menunjukkan bahwa perlakuan berpengaruh nyata $(\mathrm{P}<0,05)$ terhadap berat karkas ayam broiler. Pada Tabel 3 terlihat bahwa rata-rata persentase berat karkas ayam broiler selama penelitian secara keseluruhan adalah 61,45 \%/ekor sedangkan untuk masingmasing perlakuan yang tertinggi terdapat pada $\mathrm{P}_{2}$ yaitu $64,39 \%$ /ekor dan yang terendah pada $\mathrm{P}_{3}$ yaitu 59,10 \%/ekor. Analisis statistik menunjukkan bahwa perlakuan berpengaruh tidak nyata terhadap persentase berat karkas ayam broiler (Tabel 3).

Menurut Mugiyono et al. (1991) dan Saptono (1995), bahwa persentase karkas berhubungan erat dengan bobot badan akhir, pertumbuhan dan kualitas pakan yang dikonsumsi. Pertumbuhan dan berat badan akhir semakin meningkat maka persentase karkas juga akan meningkat pula. Perbedaan yang tidak nyata ini diduga bahwa jus lidah buaya tidak banyak berperan dalam menentukan persentase karkas ayam broiler, karena persentase karkas lebih dipengaruhi oleh pakan, umur, bangsa ternak, dan lingkungan. Hal ini menunjukkan bahwa protein berperan penting dalam pencapaian bobot karkas yang diinginkan sehingga dapat mempengaruhi persentase karkas.

Tabel 3.Rata-rata persentase berat karkas ayam broiler (\%/ekor)

\begin{tabular}{cccccr}
\hline \multirow{2}{*}{ Ulangan } & \multicolumn{5}{c}{ Perlakuan } \\
\cline { 2 - 6 } & $\mathrm{P}_{0}$ & $\mathrm{P}_{1}$ & $\mathrm{P}_{2}$ & $\mathrm{P}_{3}$ & \\
\hline 1 & 61,76 & 61,62 & 65,47 & 64,77 & \\
2 & 59,14 & 63,18 & 59,04 & 63,51 & \\
3 & 61,54 & 59,42 & 63,40 & 60,34 & \\
4 & 64,23 & 58,27 & 69,64 & 47,80 & \\
Jumlah & 246,67 & 242,50 & $25, .54$ & 236,42 & 983,13 \\
Rataan & 61,67 & 60,62 & 64,39 & 59,10 & 61,45 \\
\hline
\end{tabular}

\subsection{Pengaruh Perlakuan Terhadap Berat Non Karkas Ayam Broiler}

Pada Tabel 4 terlihat bahwa rata-rata berat non karkas ayam broiler selama penelitian secara keseluruhan adalah 325.81 g/ekor sedangkan untuk masingmasing perlakuan yang tertinggi terdapat pada $\mathrm{P}_{2}$ yaitu 371.75 g/ekor dan yang terendah pada $\mathrm{P}_{0}$ yaitu 259.25 g/ekor. Analisis statistik menunjukkan bahwa perlakuan berpengaruh tidak nyata terhadap persentase berat non karkas ayam broiler. Rata-rata persentase berat non karkas ayam broiler dapat dilihat pada Tabel 4.
Harisshinta (2009) dan Nurhayati (2008) berpendapat bahwa berat non karkas sebesar sepertiga bagian dari bobot hidup. Berat nonkarkas berbanding lurus dengan berat karkas dan bobot hidup, semakin tinggi bobot hidup maka semakin tinggi pula berat karkas dan berat nonkarkas. Jika semakin tinggi pemberian jus lidah buaya akan membuat serat kasar pakan semakin tinggi dan juga kecernaan nutrien tidak maksimal sehingga komponen non karkas kurang tumbuh secara optimal dan berpengaruh terhadap berat non karkas. Sehingga kadar air yang ada didalam tubuh ayam akan mempengaruhi berat non karkas. Karena hasil penelitian menunjukkan pemberian jus lidah buaya pada $\mathrm{P}_{2}$ lebih efisien dibandingkan dengan yang lain oleh karena itu kadar air yang semakin tinggi akan membuat berat non karkas semakin rendah. Serat kasar yang tinggi akan mempengaruhi proses pencernaan dan menghambat penyerapan nutrien dalam pakan yang berpengaruh terhadap perkembangan non karkas.

$\underline{\text { Tabel 4. Rata-rata persentase berat non karkas ayam broiler (g/ekor) }}$

\begin{tabular}{|c|c|c|c|c|c|}
\hline \multirow{2}{*}{ Ulangan } & \multicolumn{4}{|c|}{ Perlakuan } & \multirow{2}{*}{ Jumlah } \\
\hline & $\mathrm{P}_{0}$ & $\mathrm{P}_{1}$ & $\mathrm{P}_{2}$ & $\mathrm{P}_{3}$ & \\
\hline 1 & 260 & 308 & 327 & 340 & \\
\hline 2 & 222 & 295 & 417 & 348 & \\
\hline 3 & 257 & 289 & 391 & 335 & \\
\hline 4 & 298 & 432 & 352 & 342 & \\
\hline Jumlah & 1037 & 1324 & 1487 & 1365 & 5213 \\
\hline Rataan & 259,25 & 331 & 371,75 & 341,25 & 325,81 \\
\hline
\end{tabular}

\subsection{Pengaruh Perlakuan Terhadap Rata-rata Persentase Berat Lemak} Abdominal Ayam Broiler

Rata-rata berat lemak abdominal dan persentase berat abdominal ayam broiler yang diberikan jus lidah buaya dengan level berbeda tersaji pada Tabel 5 dan 6 .

Tabel 5. Rata-rata berat lemak abdominal ayam broiler (g/ekor)

\begin{tabular}{|c|c|c|c|c|c|}
\hline \multirow{2}{*}{ Ulangan } & \multicolumn{4}{|c|}{ Perlakuan } & \multirow{2}{*}{ Jumlah } \\
\hline & $\mathrm{P}_{0}$ & $\mathrm{P}_{1}$ & $\mathrm{P}_{2}$ & $\mathrm{P}_{3}$ & \\
\hline 1 & 2,51 & 12,22 & 17,88 & 11,89 & \\
\hline 2 & 2,53 & 14,03 & 14,6 & 16,29 & \\
\hline 3 & 7,51 & 10,04 & 40,4 & 20,9 & \\
\hline 4 & 11,88 & 19,15 & 17,42 & 20,57 & \\
\hline Jumlah & 24,43 & 55,44 & 90,3 & 69,65 & 239,82 \\
\hline Rataan & $6,11^{b}$ & $13,86^{\mathrm{b}}$ & $22,58^{\mathrm{a}}$ & $17,41^{\mathrm{b}}$ & 14,99 \\
\hline
\end{tabular}

Tabel 6.Rata-rata persentase berat lemak abdominal ayam broiler (\%/ekor)

\begin{tabular}{|c|c|c|c|c|c|}
\hline \multirow{2}{*}{ Ulangan } & \multicolumn{4}{|c|}{ Perlakuan } & \multirow{2}{*}{ Jumlah } \\
\hline & $\mathrm{P}_{0}$ & $\mathrm{P}_{1}$ & $\mathrm{P}_{2}$ & $\mathrm{P}_{3}$ & \\
\hline 1 & 0,27 & 1,24 & 1,52 & 1,04 & \\
\hline 2 & 0,32 & 1,40 & 1,18 & 1,32 & \\
\hline 3 & 0,80 & 1,22 & 2,89 & 1,96 & \\
\hline 4 & 1,11 & 1,53 & 1,58 & 1,68 & \\
\hline Jumlah & 2,51 & 5,39 & 7,19 & 6,00 & 21,08 \\
\hline Rataan & $0,63^{\mathrm{b}}$ & $1,35^{\mathrm{b}}$ & $1,80^{\mathrm{a}}$ & $1,50^{\mathrm{b}}$ & 1,32 \\
\hline
\end{tabular}

Pada Tabel 5 terlihat bahwa rata-rata berat lemak abdominal broiler selama penelitian secara keseluruhan adalah14,99 g/ekor sedangkan untuk masing-masing perlakuan yang tertinggi terdapat pada $\mathrm{P}_{2}$ yaitu 22,58 g/ekor dan yang terendah pada $\mathrm{P}_{0}$ yaitu 6,11 g/ekor. Analisis statistik menunjukkan bahwa perlakuan berpengaruh nyata $(\mathrm{P}<0,05)$ terhadap persentase lemak abdominal ayam broiler. Pada Tabel 6 terlihat bahwa rata-rata persentase berat lemak abdominal broiler selama penelitian secara keseluruhan adalah 1,32\%/ekor sedangkan untuk masing-masing perlakuan yang tertinggi terdapat pada $\mathrm{P}_{2}$ yaitu 1,80 \%/ekor dan yang terendah pada $\mathrm{P}_{0}$ yaitu $0,63 \%$ /ekor. Analisis statistik menunjukkan bahwa perlakuan berpengaruh nyata $(\mathrm{P}<0,05)$ terhadap persentase lemak abdominal ayam broiler. Peningkatan berat lemak abdominal pada P2 berkorelasi positif dengan berat badan ayam broiler (Tabel 3). Semakin berat ayam semakin meningkat penimbunan lemak intamuskular maupun lemak abdominal. Kubena et al., (1974) menyatakan bahwa penimbunan lemak tubuh (lemak abdomen) dipengaruhi oleh beberapa faktor yaitu temperatur, kandang atau ruang kandang, kadar energi ransum, umur dan jenis kelamin.

Lemak abdominal mempunyai hubungan dengan total lemak karkas, semakin tinggi kandungan lemak abdominal maka semakin tinggi kandungan lemak karkas pada broiler (Salam et al., 2013). Lemak abdominal merupakan salahsatu komponen lemak tubuh ayam yangterdapat pada rongga perut. Lemakabdominal didapat darilapisan yang membungkus organ pencernaan di dalam rongga perut. Hasil penelitian ini lebih rendah jika dibandingkan dengan Mide (2007) yang melaporkan bahwa berat lemak abdominal ayam broiler yang diberikan temulawak dalam ransum berkisar antara 2,31-2.63\%.

\section{Simpulan}

Berdasarkan hasil dan pembahasan diperoleh bahwa pemberian $10 \%$ jus lidah buaya dalam air minum sebagai feed additive meningkatkan berat potong dan karkas ayam broiler. 
Pustaka

Charoen Pokphand Indonesia. 2004. Feedand Nutrition In Broiler Management. Stadium General Charoen Pokphand, Fakultas Peternakan Institut Pertanian Bogor. Bogor.

Harisshinta, R. 2009. Pengaruh Penggunaan Limbah Teh dalam Pakan terhadap Persentase Karkas, Lemak Abdominal, Kandungan Lemak Daging dan Berat Organ dalam Ayam Pedaging. [Skripsi], Fakultas Peternakan Universitas Brawijaya, Malang

Kubena, L. F., J. W. Deaton , T. C. Chen and F. N. Reece. 1974. Factors Influencing the Quantity of Abdominal Fat in Broilers I. Rearing Temperature, Sex Age or Weight, and dietary Choline Chloride and Inositol Supplemen-tation. Poult. Sci, 53: 211-241.

Mide, M.Z. 2007. Konversi Ransum dan Income Over Feed and Chick Cost Broiler yang Diberikan Ransum Mengandung Berbagai Level Tepung Rimpang Temulawak (Curcumin Xanthorrhiza Roxb). Buletin Nutrisi dan Makanan Ternak, 6 (2):21-26.

Mugiyono, S., Riswantiyah dan S. Muljowati. 1991. Meningkatkan Produktivitas ayam broiler dengan pemberian berbagai bentuk pakan dan potongan paruh. Makalah seminar usaha peningkatan produktivitas peternakan dan perikanan.

Nurhayati, A. 2008. Kecernaan Bahan Kering, Serat Kasar, Selulosa dan Hemiselulosa Kayambang (S. molesta) pada Itik Lokal. [Skripsi], Fakultas Peternakan Institut Pertanian Bogor.

Salam, S., A. Fatahilah, D. Sunarti, dan Isroli. 2013. Berat Karkas Dan Lemak Abdominal Ayam Broiler Yang Diberi Jintan Hitam (Nigella sativa) Dalam Pakan Selama Musim Panas. Sains Peternakan, 11 (2) : 84-89.

Saptono, H. 1995. Pengaruh Penggunaan Ampas Brem Terhadap Presentase Karkas Ayam Broiler. Fakultas Peternakan Universitas Diponegoro. Semarang

Setiadi, D., K. Nova dan S. Tantalo. 2013. Perbandingan Bobot Hidup, Karkas, Giblet, Dan Lemak Abdominal Ayam Jantan Tipe Medium Dengan Strain Berbeda Yang Diberi Ransum Komersial Broiler. Jurnal Ilmiah Peternakan Terpadu, Vol 1 No 2.

Sinurat, A. P., T. Purwadaria, M. H. Togatorop, T. Pasaribu, I.A.K. Bintang, S. Sitompul, dan Rosida. 2002. Respon ayam pedaging terhadap penambahan bioaktif lidah buaya dalam ransum: Pengaruh berbagai bentuk dan dosis bioaktif dalam tanaman lidah buaya terhadap performans ayam pedaging. Journal Ilmu Ternak dan Veteriner, 7(2) : 69-75.

Steel, R.G.D. and J.H. Torrie. 1995. Prinsip dan Prosedur Statistika: Suatu Pendekatan Biometrik. Penerjemah: Sumantri, B. Gramedia Pustaka Utama, Jakarta. 